\title{
Drug-resistant tuberculosis in subjects included in the Second National Survey on Antituberculosis Drug Resistance in Porto Alegre, Brazil*,***
}

\author{
Tuberculose resistente em pacientes incluidos no II Inquérito Nacional de \\ Resistência aos Fármacos Antituberculose \\ realizado em Porto Alegre, Brasil**
}

\author{
Vania Celina Dezoti Micheletti, José da Silva Moreira, Marta Osório Ribeiro, \\ Afranio Lineu Kritski, José Ueleres Braga
}

\begin{abstract}
Objective: To describe the prevalence of multidrug-resistant tuberculosis (MDR-TB) among tuberculosis patients in a major Brazilian city, evaluated via the Second National Survey on Antituberculosis Drug Resistance, as well as the social, demographic, and clinical characteristics of those patients. Methods: Clinical samples were collected from tuberculosis patients seen between 2006 to 2007 at three hospitals and five primary health care clinics participating in the survey in the city of Porto Alegre, Brazil. The samples were subjected to drug susceptibility testing. The species of mycobacteria was confirmed using biochemical methods. Results: Of the 299 patients included, $221(73.9 \%)$ were men and $77(27.3 \%)$ had a history of tuberculosis. The mean age was 36 years. Of the 252 patients who underwent HIV testing, 66 (26.2\%) tested positive. The prevalence of MDR-TB in the sample as a whole was 4.7\% $(95 \% \mathrm{Cl}: 2.3-7.1)$, whereas it was $2.2 \%(95 \% \mathrm{Cl}: 0.3-4.2)$ among the new cases of tuberculosis and $12.0 \%(95 \% \mathrm{Cl}: 4.5-19.5)$ among the patients with a history of tuberculosis treatment. The multivariate analysis showed that a history of tuberculosis and a longer time to diagnosis were both associated with MDR-TB. Conclusions: If our results are corroborated by other studies conducted in Brazil, a history of tuberculosis treatment and a longer time to diagnosis could be used as predictors of MDR-TB.
\end{abstract}

Keywords: Tuberculosis/diagnosis; Drug resistance; HIV.

\section{Resumo}

Objetivo: Descrever a prevalência de tuberculose multirresistente (TBMR) em pacientes com tuberculose em uma importante cidade brasileira através do II Inquérito Nacional de Resistência aos Fármacos Antituberculose, assim como as características sociais, demográficas e clínicas desses pacientes. Métodos: De 2006 a 2007, amostras clínicas de pacientes de três hospitais e das cinco unidades básicas de saúde participantes do inquérito realizado em Porto Alegre foram coletadas e submetidas ao teste de sensibilidade aos fármacos. A confirmação das espécies de micobactérias ocorreu por métodos bioquímicos. Resultados: Foram incluídos 299 pacientes. Desses, $221(73,9 \%)$ eram homens e 77 (27,3\%) tinham história de tuberculose. A idade média foi de 36 anos. Dos 252 pacientes testados para HIV, $66(26,2 \%)$ estavam infectados. A prevalência da TBMR na amostra geral foi de 4,7\% (1C95\%: 2,3-7,1); enquanto essa foi de 2,2\% (1C95\%: 0,3-4,2) nos pacientes virgens de tratamento e de 12,0\% (1C 95\%: 4,5-19,5) naqueles com história de tratamento antituberculose. A análise multivariada mostrou que história de tuberculose e maior tempo para o diagnóstico associaram-se a TBMR. Conclusões: Caso esses resultados sejam confirmados em outros estudos no Brasil, a história de tratamento antituberculose e o maior tempo para o diagnóstico poderão ser utilizados como preditores de TBMR.

Descritores: Tuberculose/diagnóstico; Resistência a medicamentos; HIV.

*Study carried out in the Department of Health of the City of Porto Alegre, Porto Alegre, Brazil; at the Federal University of Rio Grande do Sul, Porto Alegre, Brazil; and at the Federal University of Rio de Janeiro, Rio de Janeiro, Brazil.

Correspondence to: Vania Celina Dezoti Micheletti. Rua Coronel Feijó, 473, apto. 201, Higienópolis, CEP 90520-060, Porto Alegre, RS, Brasil.

Tel. 5551 9946-0923. E-mail: vaniadezoti@uol.com.br

Financial support: This study received financial support from the Brazilian Coordenação de Aperfeiçoamento de Pessoal de Nível Superior (CAPES, Office for the Advancement of Higher Education).

Submitted: 15 July 2013. Accepted, after review: 5 March 2014.

**A versão completa em português deste artigo está disponível em www.jornaldepneumologia.com.br 


\section{Introduction}

There was a recrudescence of tuberculosis in the late 1980s, which led the World Health Organization (WHO) to declare it a public health emergency in $1993 .{ }^{(1)}$ In early 1994 , the WHO also initiated the Global Project on Anti-Tuberculosis Drug Resistance Surveillance, in collaboration with the International Union against Tuberculosis and lung Disease (IUATLD). ${ }^{(2)}$ Between 1994 and 1999, the WHO and the IUATLD compiled drug resistance data from surveys carried out in 58 countries. ${ }^{(3)}$ They found that the mean prevalence of primary multidrug-resistant tuberculosis (MDRTB), in patients with no history of tuberculosis treatment was $1.0 \%$ (range, $0-14.1 \%$ ), and that the mean prevalence of acquired MDR-TB was 9.3\% (range, 0-48.2\%). ${ }^{(3)}$

Studies conducted between 2002 and 2006 , collectively involving 90,000 patients in 81 countries, demonstrated an increase in the estimated prevalence of drug-resistant tuberculosis (DR-TB)..$^{(4,5)}$ In 2005, there were 500,000 new cases of MDR-TB worldwide, corresponding to $5 \%$ of the total number of cases of tuberculosis. In that same year, the prevalence of primary MDR-TB was 2.9\% (range, 2.2-3.6\%), whereas that of acquired MDR-TB was 15.3\% (range, 9.6-21.1\%), respectively. ${ }^{(4)}$

In 2006, cases of extensively drug-resistant tuberculosis (XDR-TB) were reported in South Africa, mostly in HIV-infected hospitalized patients. By 2009, cases of XDR-TB had been reported in various other regions of the world. ${ }^{(6)}$ Research also showed that death rates were higher in countries with an elevated prevalence of tuberculosis/HIV co-infection (which included cases of MDR-TB or XDR-TB in HIV-infected individuals), underscoring the need for effective interventions for the prevention and treatment of infection with resistant strains of Mycobacterium tuberculosis. (7)

In Brazil, reductions in incidence and mortality rates suggest that the tuberculosis situation has improved over the last ten years. However, in certain metropolitan regions of the country, there has been no improvement at all. ${ }^{(2)}$ For instance, in the southern Brazilian city of Porto Alegre, the incidence of tuberculosis increased from 97/100,000 population to $116 / 100,000$ population between 2001 and 2009, 30\% of all tuberculosis cases reported for the city being diagnosed in hospitals. That increase was accompanied by a high prevalence of tuberculosis/HIV co-infection, a decrease in the tuberculosis cure rate (from 69\% to 65\% of all treated cases) and an increase in the rate of default from treatment (from 15\% to 20\%). ${ }^{(8)}$

In 1996, the First National Survey on Antituberculosis Drug Resistance was conducted in Brazil. ${ }^{(9)}$ Participants were recruited from 13 health care facilities throughout the country, and approximately 6,000 strains of M. tuberculosis were identified. ${ }^{(9)}$ The prevalence rates of primary and acquired MDR-TB were $1.1 \%$ and $7.9 \%$, respectively. ${ }^{(10)}$ However, the survey did not assess the prevalence of HIV infection and was limited to patients treated at primary health care clinics. (10) In southern Brazil, the prevalence rates of primary and acquired MDR-TB $(0.8 \%$ and 5.8\%, respectively) were lower than the nationwide prevalence. ${ }^{(10)}$ Since then, no other epidemiological (population-based) studies of antituberculosis drug resistance have been conducted in any of the major cities of southern Brazil. Therefore, the present study aimed to characterize the prevalence of DR-TB and MDR-TB in the city of Porto Alegre, where the efficacy of tuberculosis control programs has decreased significantly in recent years. The present study was also aimed at identifying the prevalence of HIV infection and any demographic or clinical characteristics associated with antituberculosis drug resistance in a population recruited from primary health care clinics and hospitals.

\section{Methods}

The data analyzed in the present study were collected in the city of Porto Alegre as part of the Second National Survey on Antituberculosis Drug Resistance, conducted between 2006 and 2007. Between March of 2006 and December of 2007, patients were recruited from five primary health care clinics and three public hospitals. All patients provided sputum samples for smear microscopy and mycobacterial culture. The samples were also tested for resistance to rifampin, streptomycin, ethambutol, and isoniazid. However, due to the poor reproducibility of tests for resistance to streptomycin and ethambutol, those results were not considered in the present study.

On the basis of the results of the bacteriological examination, we defined DR-TB as resistance to any antituberculosis drug and MDR-TB as resistance to (at least) the combination of isoniazid and rifampin. The presence of organisms 
resistant to one or more drugs in patients with no history of tuberculosis treatment, or with prior treatments lasting one month or less, was classified as primary drug resistance. The presence of resistant microorganisms in patients with a history of tuberculosis treatments lasting over a month was classified as acquired drug resistance.

Given the differences in the expected prevalence of rifampin resistance in new patients (primary resistance) and re-treated patients (acquired resistance), minimum sample sizes were calculated for these two groups. These calculations were performed using a proportional-to-population-size cluster sampling method, taking into account the size of the tuberculosis diagnostic facilities and consequently the number of patients admitted for diagnosis and treatment at each health care facility. ${ }^{(11,12)}$

Participants were recruited from five primary health care clinics (Modelo; Navegantes; Institute for Childhood Protection and Assistance; Vila dos Comerciários; and Sanatório), as well as from three hospitals (the Nossa Senhora da Conceição Hospital of Porto Alegre; the Sanatório Partenon Hospital; and the Porto Alegre Hospital de Clínicas of the Federal University of Rio Grande do Sul School of Medicine), all located in the city of Porto Alegre. All patients who visited any of these health care centers during the recruitment period and were suspected of having pulmonary tuberculosis were eligible for participation. Suspected pulmonary tuberculosis was defined as the presence of respiratory symptoms or clinical or radiological signs of tuberculosis, as per the Brazilian National Guidelines for the Control of Tuberculosis. ${ }^{(13)}$ Mycobacterial cultures were carried out for all clinical samples, regardless of the sputum smear test results.

Eligible patients were included in the study if they met one of the two following criteria: being classified as a new case (no history of tuberculosis treatment) with culture-positive pulmonary tuberculosis (regardless of smear test results); and having a history of tuberculosis treatment (relapse or history of default from tuberculosis treatment), presenting with culturepositive pulmonary tuberculosis, or having used antituberculosis drugs in the 30 days prior to survey participation and sputum sample collection. We applied the following exclusion criteria: being under 18 years of age; being pregnant; and having negative culture results (regardless of the smear microscopy results) or no drug susceptibility testing (DST) results (i.e., DST not carried out in accordance with the Brazilian National Guidelines for the Control of Tuberculosis). ${ }^{(13)}$ Sputum samples were collected prior to the beginning of treatment. Patients were not required to consent to HIV testing in order to participate in the survey.

Patients were interviewed at the health care facilities involved, in rooms reserved specifically for that purpose, by researchers trained in data collection via an instrument with pre-coded closed questions. The instrument was designed to assess the following variables: sociodemographic data (gender, age, and place of residence); willingness to undergo HIV testing; time to diagnosis (hereafter time to diagnosis); history of hemoptysis; history of tuberculosis (for this variable, the self-reported answers-"yes", "no”, or "don't know"-were verified against the patient records available at the primary health care clinics or in other patient record systems); use of antituberculosis drugs; cough with expectoration for more than 3 weeks; previous chest $X$-ray; previous sputum testing; previous use of antituberculosis drugs; and case type (new case, re-treatment after cure, re-treatment after default from treatment, chronic treatment failure, or unknown). All patients were informed that HIV testing is a routine assessment procedure and were invited to undergo said testing. Researchers were trained in the provision of pre- and post-HIV test counseling. The samples collected for HIV testing were sent to a laboratory for diagnostic testing with ELISA. Patients were informed of the HIV test results and, when necessary, were offered counseling and directed to the AIDS treatment facility nearest to their place of residence.

Two sputum samples were collected from each patient at the respective health care facilities. Sputum smears were then examined using ZiehlNeelsen staining. Procedures for smear microscopy preparation, staining and reading were conducted according to international guidelines. ${ }^{(14,15)}$ Clinical samples were sent to the Rio Grande do Sul State Referral Laboratory for processing. After decontamination, material was inoculated into two tubes containing löwenstein-Jensen (LJ) medium. Cultures were incubated at $37^{\circ} \mathrm{C}$ for up to 6 weeks, until colony growth was observed. Cultures were inspected $48 \mathrm{~h}$ after inoculation and weekly until day 42 of incubation. Strain 
morphology and pigmentation were observed, and the date on which colonies appeared was recorded. These procedures were conducted according to the tuberculosis guidelines established by the Brazilian National Ministry of Health. ${ }^{(16)}$ We identified strains of M. tuberculosis by growth inhibition test, using p-nitrobenzoic acid at a concentration of $500 \mu \mathrm{g}$ per $1 \mathrm{~mL}$ of $\mathrm{LJ}$ medium, as well as niacin and nitrate tests. ${ }^{(15)}$

Indirect susceptibility testing was performed on the samples obtained from the participants. Culture growth on day 28 of incubation determined the final results, which were interpreted in relation to the resistance criteria recommended in the WHO guidelines (i.e., 1\%). ${ }^{(14)}$ For each lot of $\mathrm{LJ}$ medium and each antituberculosis drug tested, DST was also conducted on the reference strain of $M$. tuberculosis (H37Rv), which was thus used as a susceptible control. All laboratories involved in testing used a double-blind method for internal quality control. In addition, 100\% of the samples identified as drug-resistant were retested by another referral laboratory, as were $15 \%$ of those identified as susceptible.

A database was created using the EpiData program (EpiData Association, Odense, Denmark). Data analyses comprised prevalence estimates, confidence intervals (considered significant at 5\%) and group comparisons. Chi-square tests were used in comparisons between individuals infected with resistant strains and those infected with susceptible strains. Measures of association, such as prevalence ratios, were calculated using STATA software, version 10.

The present study was approved by the Research Ethics Committee of the Porto Alegre Municipal Health Department (Protocol no. 001.053413.05.9; approved 16 December, 2005). The nationwide project (the Second National Survey on Antituberculosis Drug Resistance) was approved by the National Committee for Research Ethics (Protocol no. 25000.178623/200480; approved 24 May, 2005). All participating patients (or their legal guardians) gave written informed consent.

\section{Results}

Of all patients with suspected pulmonary tuberculosis seen at the participating health care facilities, 714 were eligible for participation in the present study. Of those 714 patients, 208 $(29.1 \%)$ and $96(13.4 \%)$ were found to be smear positive-culture positive and smear negative-culture positive, respectively, 299 (41.9\%) subsequently undergoing DST (Figure 1).

Table 1 displays the demographic and clinical characteristics of the survey participants. The majority of participants were young adults, and the male-to-female ratio was $3: 1$. There were no gender or age differences between the patients with a history of treatment for tuberculosis and those without.

One fifth of patients reported having undergone prior HIV testing. The frequency of HIV testing in the two months prior to the survey was higher in patients with a history of tuberculosis treatment than in those without. Although the mean time to diagnosis was longer in the patients with a history of tuberculosis than in those without, it was greater than three months in both groups.

Resistance to at least one antituberculosis drug (DR-TB) and combined resistance to at least isoniazid and rifampin (MDR-TB) were observed in $14.0 \%$ and $4.7 \%$ of the patients, respectively. Drug resistance was eight times greater in the patients with a history of tuberculosis $(p=0.01)$. Isoniazid monoresistance was more common than was rifampin monoresistance. The prevalence rates of primary and acquired MDR-TB were $2.2 \%$ and $12.0 \%$, respectively. Positive HIV test results were seen in $26 \%$ of the patients, and the frequency of such results was higher in the patients with a history of tuberculosis (Table 2). As can be seen in Table 3, HIV infection was not found to be associated with DR-TB or MDR-TB. However, the time to diagnosis was associated with DR-TB and MDR-TB. In patients with a history of hemoptysis, there was a higher prevalence of DR-TB but not of MDR-TB.

In summary, the bivariate analyses indicated that the following variables were associated with DR-TB: tuberculosis re-treatment; time to diagnosis; and history of hemoptysis. We also found that re-treatment was associated with MDR-TB, as was the time to diagnosis. Multivariate analyses revealed that DR-TB was independently associated with tuberculosis re-treatment and with the time to diagnosis. When this calculation was adjusted for the influence of other variables (Table 3), only the time to diagnosis was associated with MDR-TB.

\section{Discussion}

The prevalence rates of primary and acquired MDR-TB observed in the present study $(2.2 \%$ 


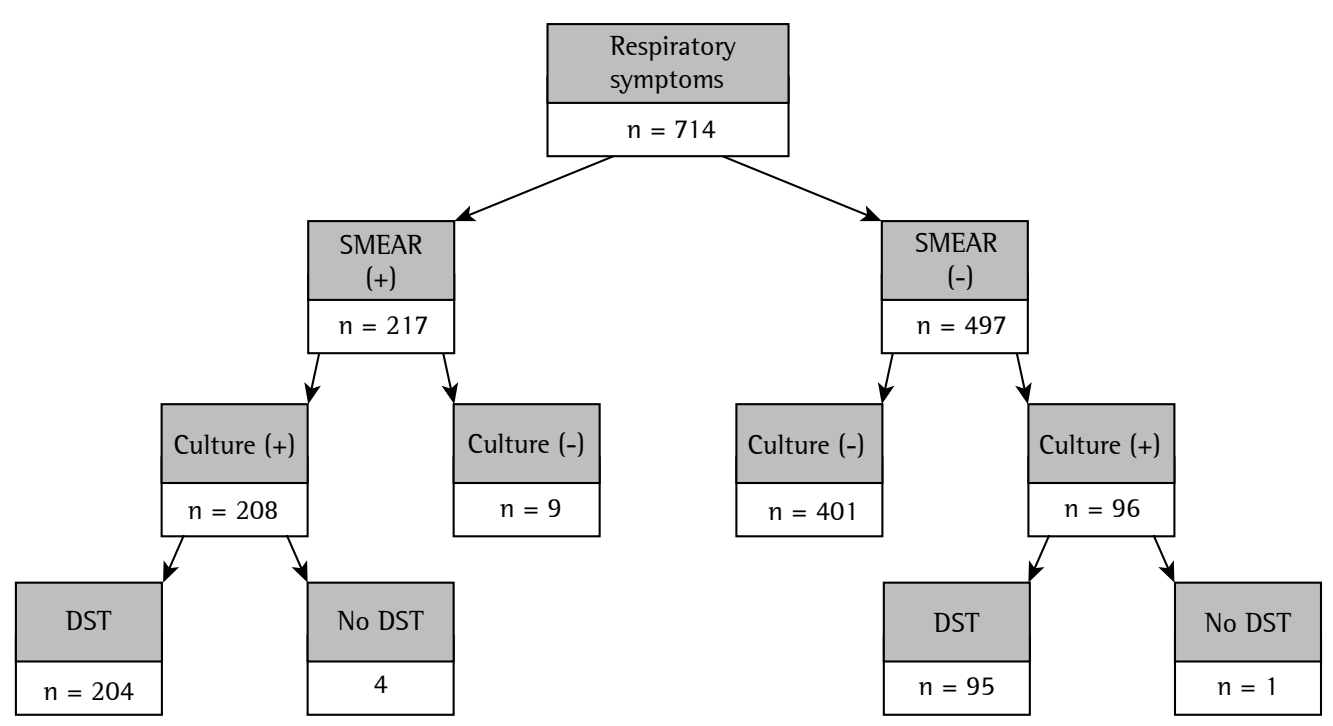

Figure 1 - Patient distribution according to laboratory tests conducted in Porto Alegre, 2006-2007. DST: drug susceptibility testing

and $12.0 \%$, respectively) were higher than those reported in the First National Survey on Antituberculosis Drug Resistance (1.1\% and 7.9\%, respectively), which was carried out in Brazil in 1996, and in the International WHO-IUATLD report, which was conducted in 58 countries between 1994 and 1999 (1.0\% and 9.3\%, respectively). ${ }^{(3)}$ However, the present estimates of primary and acquired MDR-TB prevalence were lower than the respective rates of $2.9 \%$ and $15.3 \%$ reported in the WHO-IUATLD survey conducted between 2002 and 2007. ${ }^{(3)}$ The prevalence rates of MDR-TB in Lithuania and Azerbaijan, for instance, were $14.4 \%$ and $22.3 \%$, respectively. ${ }^{(3,10)}$ The high prevalence of primary MDR-TB found in the present study (2.2\%) might be attributable to the increase in the rate of default from treatment observed over the last 10 years in the city of Porto Alegre. ${ }^{(8)}$

Our results suggest that DR-TB is associated with re-treatment and with a longer time to diagnosis. These conditions, in turn, might represent the consequences of delayed diagnosis and lack of prompt treatment in cases of tuberculosis, as has been suggested in previous studies. ${ }^{(17-19)}$ Although difficulties in the diagnosis of tuberculosis and the detection of resistance to antituberculosis drugs-even after the implementation of the directly observed treatment, short-course (DOTS) strategy or the DOTS-plus strategy-have been reported in a number of countries, few studies have evaluated the variables associated with delayed detection of DR-TB. ${ }^{(20)} A$ recent analysis of tuberculosis transmission and delayed diagnosis suggested that the duration of this delay is the main obstacle in controlling the tuberculosis epidemic. ${ }^{(17)}$ Storla et al. ${ }^{(19)}$ also suggested that repeated attempts by patients to seek treatment at the same level of health care and the inconclusive test results obtained at that level are responsible for delaying the diagnosis of tuberculosis.

In the present sample, the mean time from symptom onset to a diagnosis of tuberculosis was 110.9 days, which is longer than the delays reported for other developing countries (61.3 days) and for developed countries (67.8 days). (21) This figure is also higher than (or comparable to) that reported in surveys conducted in other major Brazilian cities: 68 days in Rio de Janeiro; 110 days in Vitória; and 90 days in Recife..$^{(7,22,23)}$

Among our sample of patients in the city of Porto Alegre, the association found between a history of tuberculosis treatment and the time to diagnosis, which was 184.8 days for those with such a history, has not been observed in surveys conducted in other Brazilian cities, such as Rio de Janeiro. ${ }^{(23)}$ One of the risk factors for delayed detection of DR-TB is an increased probability of transmission to individuals at home or in hospital environments, or even in prisons or shelters. The chain of transmission continues and leads to further contamination and aggravation of existing cases of tuberculosis, contributing to 
Table 1 - Clinical and demographic characteristics of participants in the Second National Survey on Antituberculosis Drug Resistance, in Porto Alegre, Brazil. 2006-2007.

\begin{tabular}{|c|c|c|c|}
\hline \multirow[t]{3}{*}{ Variable } & \multicolumn{2}{|c|}{$\begin{array}{l}\text { History of tuberculosis } \\
\text { treatment }\end{array}$} & \multirow[t]{2}{*}{ Total } \\
\hline & No & Yes & \\
\hline & $\left(n=224^{a}\right)$ & $\left(\mathrm{n}=75^{\mathrm{a}}\right)$ & $\left(n=299^{a}\right)$ \\
\hline Age (years), mean & 35.0 & 38.0 & 36.0 \\
\hline \multicolumn{4}{|l|}{ Gender, n (\%) } \\
\hline Male & $165(73.6)$ & $56(74.7)$ & $221(73.9)$ \\
\hline Female & $59(26.4)$ & $19(25.3)$ & $78(26.1)$ \\
\hline \multicolumn{4}{|l|}{ HIV testing in the past 2 months, $n(\%)$} \\
\hline Yes & $37(18.7)$ & $17(27.9)$ & $54(20.8)$ \\
\hline No & $161(81.3)$ & $44(72.1)$ & $205(79.2)$ \\
\hline Consented to HIV testing, $\mathrm{n}(\%)$ & $123(63.4)$ & 34 (57.6) & $157(62.1)$ \\
\hline Time to diagnosis (days), mean & 86.6 & 184.8 & 110.9 \\
\hline \multicolumn{4}{|c|}{ Self-reported history of tuberculosis, n (\%) } \\
\hline Yes & $5(2.4)$ & $72(100.0)$ & 77 (27.3) \\
\hline No & $202(97.6)$ & & $202(72.7)$ \\
\hline \multicolumn{4}{|l|}{ Productive cough for > 3 weeks, n (\%) } \\
\hline Yes & $93(45.4)$ & 67 (91.8) & $160(57.5)$ \\
\hline No & $112(54.6)$ & $6(8.2)$ & $118(42.5)$ \\
\hline \multicolumn{4}{|c|}{ Hemoptysis, chest pain, or other symptom of lung disease, $n(\%)$} \\
\hline Yes & $70(34.1)$ & 55 (73.3) & $125(45.0)$ \\
\hline No & $135(65.9)$ & $18(26.7)$ & $153(55.0)$ \\
\hline \multicolumn{4}{|l|}{ Chest X-ray, n (\%) } \\
\hline Yes & $125(61.0)$ & 70 (95.9) & $195(70.1)$ \\
\hline No & $80(39.0)$ & $3(4.1)$ & $83(29.9)$ \\
\hline \multicolumn{4}{|l|}{ Previous sputum testing, $\mathrm{n}(\%)$} \\
\hline Yes & $70(34.8)$ & 73 (98.6) & $143(52.0)$ \\
\hline No & $131(65.2)$ & $1(1.4)$ & $132(48.0)$ \\
\hline \multicolumn{4}{|c|}{ Antituberculosis medication for $>1$ month, $\mathrm{n}(\%)$} \\
\hline Yes & $6(3.1)$ & 73 (98.6) & 79 (29.6) \\
\hline No & $187(96.9)$ & $1(1.4)$ & $188(70.4)$ \\
\hline
\end{tabular}

aThe maximum possible numbers of patients; because of missing data, the values for some variables are based on smaller numbers.

the worldwide epidemic. In Porto Alegre, delayed detection of DR-TB is one of the main aggravating factors of the epidemiological situation. This might be attributable to flaws in the health care system, because patients often continue to visit health care facilities until receiving a diagnosis. Therefore, variables related to patient behavior and to the health care system contribute to delays in the detection of DR-TB.

The mean age and the male-to-female ratio observed in the present study were similar to those described by the Porto Alegre Municipal Health Department, as well as in the national and international literature. ${ }^{(20,24-26)} \mathrm{A}$ high number of HIV-infected patients were also found in the sample. That might be explained by the type of health care facilities investigated in the current study. It is possible that some of those facilities had multidisciplinary teams and treated patients who were referred from other health care facilities. We also found that patients with a history of tuberculosis treatment were more likely to have undergone HIV testing, probably because they sought diagnostic and treatment services via tuberculosis control programs within which HIV testing has become a routine requirement.

The responses to the screening questions for a history of tuberculosis treatment indicated that $61 \%$ of previously untreated patients had previously undergone chest X-ray, even though the Brazilian National Ministry of Health does not recommend X-ray screening in patients with a productive cough and suspected tuberculosis. ${ }^{(13)}$ In the present study, a history of tuberculosis 
Table 2 - Prevalence of combined, primary, and acquired resistance to antituberculosis drugs and HIV infection among participants in the Second National Survey on Antituberculosis Drug Resistance, in Porto Alegre, Brazil. 2006-2007.

\begin{tabular}{|c|c|c|c|c|c|c|c|c|c|}
\hline \multirow[t]{2}{*}{ Variable } & \multicolumn{3}{|c|}{$\begin{array}{l}\text { No history of TB treatment } \\
\text { (primary resistance) }\end{array}$} & \multicolumn{3}{|c|}{$\begin{array}{l}\text { History of TB treatment } \\
\text { (acquired resistance) }\end{array}$} & \multicolumn{3}{|c|}{ Combined resistance } \\
\hline & $\mathrm{n}$ & $\begin{array}{c}\text { Prevalence, } \\
\%\end{array}$ & $95 \% \mathrm{Cl}$ & $n$ & $\begin{array}{l}\text { Prevalence, } \\
\%\end{array}$ & $95 \% \mathrm{Cl}$ & $n$ & $\begin{array}{l}\text { Prevalence, } \\
\%\end{array}$ & $95 \% \mathrm{Cl}$ \\
\hline $\begin{array}{l}\text { Drug } \\
\text { susceptibility }\end{array}$ & 224 & 91.5 & $87.9-95.2$ & 75 & 68.0 & $57.2-78.8$ & 299 & 85.6 & 81.7-89.7 \\
\hline Any resistance & 224 & 8.5 & $4.8-12.1$ & 75 & 32.0 & $21.2-42.8$ & 299 & 14.4 & $10.4-18.4$ \\
\hline $\mathrm{INH}$ & 224 & 7.1 & $3.7-10.5$ & 75 & 29.3 & $18.8-39.9$ & 299 & 12.7 & $8.9-16.5$ \\
\hline RIF & 224 & 2.2 & $0.3-4.2$ & 75 & 13.3 & $5.4-21.2$ & 299 & 5.0 & $2.5-7.5$ \\
\hline Monoresistance & 224 & 4.9 & $2.0-7.8$ & 75 & 18.7 & $9.6-27.7$ & 299 & 8.4 & $5.2-11.5$ \\
\hline $\mathrm{INH}$ & 224 & 4.9 & $2.0-7.8$ & 75 & 17.3 & $8.6-26.1$ & 299 & 8.0 & $4.9-11.1$ \\
\hline RIF & 224 & 0.0 & $0.0-0.0$ & 75 & 1.3 & $0.0-3.9$ & 299 & 0.3 & $0.0-0.9$ \\
\hline $\begin{array}{l}\text { Multidrug } \\
\text { resistance }\end{array}$ & & & & & & & & & \\
\hline $\mathrm{INH}+\mathrm{RIF}$ & 224 & 2.2 & $0.3-4.2$ & 75 & 12.0 & $4.5-19.5$ & 299 & 4.7 & $2.3-7.1$ \\
\hline $\begin{array}{l}\text { Resistance } \\
\text { to } 1 \text { drug }\end{array}$ & 224 & 4.9 & $2.0-7.8$ & 75 & 18.7 & $9.6-27.7$ & 299 & 8.4 & $5.2-11.5$ \\
\hline $\begin{array}{l}\text { Resistance } \\
\text { to } 2 \text { drugs }\end{array}$ & 224 & 2.2 & $0.3-4.2$ & 75 & 12.0 & $4.5-9.5$ & 299 & 4.7 & $2.3-7.1$ \\
\hline HIV infection & 185 & 23.8 & $17.6-30.0$ & 67 & 32.8 & $23.1-44.4$ & 252 & 26.2 & $20.7-31.6$ \\
\hline
\end{tabular}

Table 3 - Variables associated with drug resistance and multidrug resistance, in bivariate and multivariate analyses, among participants in the Second National Survey on Antituberculosis Drug Resistance, in Porto Alegre, Brazil. 2006-2007.

\begin{tabular}{|c|c|c|c|c|c|c|c|c|c|}
\hline \multirow[t]{3}{*}{ Variable } & \multirow[t]{3}{*}{$\mathrm{n}$} & \multicolumn{4}{|c|}{ Bivariate analysis } & \multicolumn{4}{|c|}{ Multivariate analysis } \\
\hline & & \multicolumn{2}{|c|}{ Resistance } & \multicolumn{2}{|c|}{$\begin{array}{l}\text { Multidrug } \\
\text { resistance }\end{array}$} & \multicolumn{2}{|c|}{ Resistance } & \multicolumn{2}{|c|}{$\begin{array}{l}\text { Multidrug } \\
\text { resistance }\end{array}$} \\
\hline & & PR & $95 \% \mathrm{Cl}$ & PR & $95 \% \mathrm{Cl}$ & PR & $95 \% \mathrm{Cl}$ & PR & $95 \% \mathrm{Cl}$ \\
\hline \multicolumn{10}{|l|}{ Re-treatment } \\
\hline No & 224 & 1.00 & & 1.00 & & 1.00 & & & \\
\hline Yes & 75 & 5.08 & $2.58-9.98$ & 5.97 & $1.93-18.44$ & 4.10 & $1.61-10.41$ & 4.96 & $0.87-28.44$ \\
\hline \multicolumn{10}{|l|}{ HIV infection } \\
\hline No & 186 & 1.00 & & 1.00 & & 1.00 & & 1.00 & \\
\hline Yes & 66 & 0.72 & $0.31-1.65$ & 1.22 & $0.30-4.85$ & 0.31 & $0.09-1.08$ & 0.20 & $0.01-2.63$ \\
\hline Time to diagnosis (days) & 258 & $1.00^{\mathrm{a}}$ & $1.00-1.00^{\mathrm{b}}$ & $1.00^{c}$ & $1.00-1.00^{\mathrm{d}}$ & $1.00^{\mathrm{e}}$ & $1.00-1.00^{f}$ & $1.00^{\mathrm{g}}$ & $1.00-1.00^{\mathrm{h}}$ \\
\hline \multicolumn{10}{|c|}{ History of hemoptysis } \\
\hline No & 153 & 1.00 & & 1.00 & & 1.00 & & 1.00 & \\
\hline Yes & 125 & 2.03 & $1.03-4.03$ & 2.30 & $0.75-7.04$ & 0.94 & $0.37-2.37$ & 0.50 & $0.09-2.62$ \\
\hline
\end{tabular}

PR: prevalence ratio. ${ }^{\mathrm{a}}$ observed value: 1.001 ; ${ }^{\mathrm{b}}$ observed value: $1.0003-1.002$; ${ }^{\mathrm{c}}$ observed value: 1.001 ; ${ }^{\mathrm{d}}$ observed value:

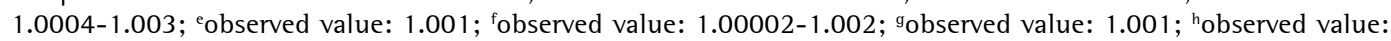
1.0001-1.003.

symptoms was investigated through questions related to hemoptysis, chest pain, and other symptoms of pulmonary tuberculosis. Such symptoms were identified in $45 \%$ of the study sample and were more common in patients with a history of tuberculosis treatment, as would be expected. It is of note that we also investigated hemoptysis, which is a less common symptom that presents later in the course of illness. ${ }^{(27)}$

The frequency of HIV infection among our study subjects was elevated but lower than that reported in the Brazilian National Case Registry Database for Porto Alegre. ${ }^{(8)}$ Our results differed from those in the literature in that the incidence 
of DR-TB in HIV-infected patients with a history of tuberculosis treatment was higher in our sample $(32.8 \%)$. A study conducted in the state of Santa Catarina (also in southern Brazil) found that the prevalence of HIV infection was higher in patients who had never been treated for tuberculosis than in those with a history of tuberculosis treatment $\left(20 \%\right.$ vs. $9 \%$ ). ${ }^{(28)}$ Our findings also support the hypothesis that the frequency of DR-TB is higher in regions where there are high rates of default from treatment.

The results of the present study call for awareness of tuberculosis control strategies by health care authorities, managers, and workers, in order to improve the health situation in the region studied. There is an urgent need to increase treatment coverage, reduce the rate of default from treatment, and identify strategies for early diagnosis of DR-TB and MDR-TB at primary health care clinics and hospitals in Porto Alegre. Effective strategies could include new diagnostic tests (liquid culture or molecular testing) or the use of clinical prediction rules. The latter method was suggested by researchers in Peru, a country with a high prevalence of DR-TB, where significant technical and political efforts have been made toward the implementation of programs for the control of DR-TB and MDR-TB. ${ }^{(29)}$

In the present study, it was possible to analyze the epidemiological behavior of DR-TB and the variables associated with this condition in a group of patients included in the Second National Survey on Antituberculosis Drug Resistance, which was conducted in the city of Porto Alegre. A longer time from symptom onset to a diagnosis of tuberculosis and history of tuberculosis treatment were found to be associated with the occurrence of DR-TB and MDR-TB. If our results are corroborated by other studies conducted in Brazil, these variables could be used as predictors of MDR-TB, thus contributing to the investigation and implementation of appropriate drug therapy. In addition, these findings could promote lower morbidity and mortality rates, as well as lowering the risk of tuberculosis transmission within the community.

\section{References}

1. World Health Organization. Global tuberculosis control: WHO report 2011. Geneva: WHO; 2011.

2. Brasil. Ministério da Saúde. Programa Nacional de Controle da Tuberculose, Departamento de Vigilância Epidemiológica [homepage on the Internet]. Situação da tuberculose no Brasil e no mundo: Secretaria de Vigilância em Saúde; 2010 [cited 2012 Feb 23]. Available from:. http://www.fundoglobaltb.org.br/download/ Apresentacao_geral_Draurio_Barreira.pdf

3. World Health Organization. Division of Communicable Diseases, WHO/IUATLD Global Project on Anti-Tuberculosis Drug Resistance Surveillance. Anti-tuberculosis drug resistance in the world/Report 2: prevalence and trends. Geneva: WHO; 2000.

4. Kritski AL. Multidrug-resistant tuberculosis emergence: a renewed challenge. J Bras Pneumol. 2010;36(2):157-8. PMid:20485934. http://dx.doi.org/10.1590/ S1806-37132010000200001

5. World Health Organization, WHO/IUATLD Global Project on Anti-Tuberculosis Drug Resistance Surveillance. Antituberculosis drug resistance in the world: fourth global report. Geneva: WHO; 2008.

6. World Health Organization. Multidrug and extensively drug-resistant TB (M/XDR-TB): 2010 global report on surveillance and response. Geneva: WHO; 2010.

7. Maciel EL, Golub JE, Peres RL, Hadad DJ, Fávero JL, Molino LP, et al. Delay in diagnosis of pulmonary tuberculosis at a primary health clinic in Vitoria, Brazil. Int J Tuberc Lung Dis. 2010;14(11):1403-10. PMid:20937179 PMCid:PMC3697918

8. Calixto M, Moresco MA, Struks MdG, Ricaldi V, Zancan $\mathrm{P}$, Ouriques MM, et al. Uma análise histórica da situação da tuberculose em Porto Alegre. In: Secretaria Municipal de Saúde de Porto Alegre. Coordenadoria Geral de Vigilância em Saúde. Equipe de Vigilância das Doenças Transmissiveis. Boletim Epidemiológico 42. Porto Alegre: a Secretaria; 2010.

9. Brasil, Ministério da Saúde. Secretaria de Vigilância em Saúde. Centro de Referência Professor Hélio Fraga. Projeto MSH. Sistema de vigilância epidemiológica da tuberculose multirresistente. Rev Bras Pneumol Sanit. 2007;15(1):39-46.

10. Braga JU, Barreto AM, Hijjar MA. Inquérito epidemiológico da resistência às drogas usadas no tratamento da tuberculose no Brasil 1995-97, IERDTB. Parte 111: principais resultados. Bol Pneumol Sanit. 2003;11(1):76-81.

11. Brasil. Ministério da Saúde. Il Inquérito Nacional de Resistência a Drogas em Tuberculose: protocolo. Brasília: Secretaria de Vigilância em Saúde; 2005.

12. World Health Organization. Guidelines for surveillance of drug resistance in tuberculosis. Geneva: World Health Organization; 2001.

13. Brasil, Ministério da Saúde. Programa Nacional de Controle da Tuberculose. Departamento de Vigilância Epidemiológica [homepage on the Internet]. Manual de recomendações para o controle da tuberculose no Brasil, 2011. [cited 2012 Feb 22]. Available from:. http:// portal.saude.gov.br/portal/arquivos/pdf/manual_de_ recomendacoes_controle_tb_novo.pdf

14. Centro Panamericano de Zoonosis. Manual de normas y procedimientos técnicos para la bacteriología de la tuberculosis. Parte l. La muestra. El examen microscópico. Buenos Aires: CEPANZ0; 1988.

15. Unión Internacional Contra la Tuberculosis y Enfermedades Respiratorias. Guía técnica para recolección, conservación y transporte de las muestras de estupo y examen por microscopia directa para la tuberculosis. Bol Uno Int Tuberc. 1978;(Suppl 2).

16. Brasil. Ministério da Saúde. Manual de bacteriologia da tuberculose. Rio de Janeiro: Centro de Referência Professor Hélio Fraga; 1994. 
17. Uys PW, Warren RM, van Helden PD. A threshold value for the time delay to TB diagnosis. PLoS One. 2007;2(8):e757. PMid:17712405 PMCid:PMC1942086. http://dx.doi. org/10.1371/journal.pone.0000757

18. Lambert ML, Van der Stuyft P. Delays to tuberculosis treatment: shall we continue to blame the victim? Trop Med Int Health. 2005;10(10):945-6. PMid:16185227. http://dx.doi.org/10.1111/j.1365-3156.2005.01485.x

19. Storla DG, Yimer S, Bjune GA. A systematic review of delay in the diagnosis and treatment of tuberculosis. BMC Public Health. 2008;8:15. PMid:18194573 PMCid:PMC2265684. http://dx.doi.org/10.1186/1471-2458-8-15

20. World Health Organization. Communicable Diseases. Global tuberculosis control: surveillance, planning, financing. WHO report 2003. Geneva: WHO; 2003.

21. Sreeramareddy CT, Panduru KV, Menten J, Van den Ende J. Time delays in diagnosis of pulmonary tuberculosis: a systematic review of literature. BMC Infect Dis. 2009;9:91. PMid:19519917 PMCid:PMC2702369. http://dx.doi. org/10.1186/1471-2334-9-91

22. dos Santos MA, Albuquerque MF, Ximenes RA, Lucena-Silva NL, Braga C, Campelo AR, et al. Risk factors for treatment delay in pulmonary tuberculosis in Recife, Brazil. BMC Public Health. 2005;5:25. PMCid:PMC1084352. http:// dx.doi.org/10.1186/1471-2458-5-25 PMid:15777473

23. Machado AC, Steffen RE, Oxlade O, Menzies D, Kritski A, Trajman A. Factors associated with delayed diagnosis of pulmonary tuberculosis in the state of Rio de Janeiro, Brazil. J Bras Pneumol. 2011;37(4):512-20. PMid:21881742. http://dx.doi.org/10.1590/S1806-37132011000400014
24. Brasil. Ministério da Saúde. Departamento de Vigilância Epidemiológica [homepage on the Internet]. Programa Nacional de Controle da Tuberculose Brasília: Secretaria de Vigilância em Saúde; 2011 [cited 2012 Fev 26]. Available from:. http://portal.saude.gov.br/portal/arquivos/ pdf/2ap_padrao_tb_20_10_11.pdf

25. Marques M, Cunha EA, Ruffino-Netto A, Andrade SM. Drug resistance profile of Mycobacterium tuberculosis in the state of Mato Grosso do Sul, Brazil, 2000-2006. J Bras Pneumol. 2010;36(2):22431. PMid:20485944

26. Secretaria Municipal de Saúde de Porto Alegre. Coordenadoria Geral de Vigilância em Saúde. Equipe de Vigilância das Doenças Transmissiveis. Boletim Epidemiológico 23. Porto Alegre: Secretaria Municipal de Saúde; 2004.

27. Brasil. Ministério da Saúde. Tuberculose. Guia de vigilância epidemiológica. Brasília: Ministério da Saúde. Fundação Nacional de Saúde; 2002.

28. Gomes C, Rovaris DB, Severino JL, Gruner MF. Perfil de resistência de M. tuberculosis isolados de pacientes portadores do HIV/AIDS atendidos em um hospital de referência. J Pneumol. 2000;26(1):25-9. http://dx.doi. org/10.1590/S0102-35862000000100006

29. Martinez D, Heudebert G, Seas C, Henostroza G, Rodriguez M, Zamudio C et al. Clinical prediction rule for stratifying risk of pulmonary multidrugresistant tuberculosis. PLoS One. 2010;5(8):e12082. PMCid:PMC2920322. PMid:20711459. http://dx.doi. org/10.1371/journal.pone.0012082

\section{About the authors}

\section{Vania Celina Dezoti Micheletti}

Nurse. Federal University of Rio Grande do Sul, Porto Alegre, Brazil.

\section{José da Silva Moreira}

Adjunct Professor. Department of Pulmonology, Federal University of Rio Grande do Sul, Porto Alegre, Brazil.

\section{Marta Osório Ribeiro}

Pharmacist. Institute of Microbiology, Federal University of Rio de Janeiro, Rio de Janeiro, Brazil.

\section{Afranio Lineu Kritski}

Full Professor. Department of Pulmonology, Federal University of Rio de Janeiro School of Medicine, Rio de Janeiro, Brazil.

\section{José Veleres Braga}

Adjunct Professor. Department of Collective Health, Rio de Janeiro State University; and Public Health Researcher. Oswaldo Cruz Foundation, Rio de Janeiro, Brazil. 